\title{
FACTORS AFFECTING TERTIARY PREVENTIVE BEHAVIORS AMONG PATIENTS WITH HIGH BLOOD PRESSURE
}

\author{
Angga Ferdianto ${ }^{1,2}$, Didik Gunawan Tamtomo3), Endang Sutisna Sulaeman ${ }^{3}$ ) \\ 1)School of Health Sciences Ngudia Husada Madura, Bangkalan \\ 2)Masters Program in Public Health, Universitas Sebelas Maret \\ 3)Faculty of Medicine, Universitas Sebelas Maret
}

\begin{abstract}
Background: The incidence of hypertension in Indonesia has remained high. Tertiary prevention of hypertension in hypertensive patients is needed to improve their knowledge toward hypertension, health belief, the practice of life-style modification, and the ability to control blood pressure. The purpose of this study was to examine factors affecting tertiary preventive behaviors among patients with high blood pressure.

Subjects and Method: A cross-sectional study was carried out at 25 integrated health posts (posbindu) in Surakarta, Centra Java, from September to October 2019. A sample of 200 hypertensive patients was selected by stratified random sampling. The dependent variable was tertiary preventive behavior. The independent variables were education, attitude, subjective norm, perceived behavior control, intention, cadre support, and peer support. The data were collected by questionnaire and analyzed by a mutiple logistic regression.

Results: Tertiary preventive behaviors in hypertensive patients increased with education $\geq$ Senior high school $(\mathrm{OR}=3.58 ; 95 \% \mathrm{CI}=1.62$ to $7.90 ; \mathrm{p}=0.002)$, positive attitude $(\mathrm{OR}=$ 4.01; 95\% $\mathrm{CI}=1.69$ to $9.54 ; \mathrm{p}=0.002)$, supportive subjective norm $(\mathrm{OR}=3.88 ; 95 \% \mathrm{CI}=1.65$ to 9.16; $\mathrm{p}=0.002)$, strong perceived behavior control $(\mathrm{OR}=2.86 ; 95 \% \mathrm{CI}=1.24$ to $6.59 ; \mathrm{p}=$ o.013), strong intention ( $\mathrm{OR}=2.44 ; 95 \% \mathrm{CI}=1.13$ to $5.26 ; \mathrm{p}=0.023)$, strong cadre support $(\mathrm{OR}=4.59 ; 95 \% \mathrm{CI}=2.07$ to $10.18 ; \mathrm{p}<0.001)$, and strong peer support $(\mathrm{OR}=3.77 ; 95 \% \mathrm{CI}=$ 1.68 to $8.42 ; \mathrm{p}=0.001)$.

Conclusion: Tertiary preventive behaviors in hypertensive patients increases with education $\geq$ Senior high school, positive attitude, supportive subjective norm, strong perceived behavior control, strong intention, strong cadre support, and strong peer support.
\end{abstract}

Keywords: tertiary prevention, hypertention, theory of planned behavior

\section{Correspondence:}

Angga Ferdianto. School of Health Sciences Ngudia Husada Madura. Jl. RE Martadinata 45, Mlajah, Bangkalan 69116, East Java, Indonesia. Email: angga.rmd@gmail.com. Mobile: +6285746555354 .

The $7^{\text {th }}$ International Conference on Public Health

Solo, Indonesia, November 18-19, 2020 | 88

https://doi.org/10.26911/the7thicph.01.43 